\title{
Examination of the Creation of a Positive Culture of Teaching and Learning through Classroom Management
}

\author{
John Ramaphakela ${ }^{1}$, Dickson Mdhlalose ${ }^{2}$ \\ ${ }^{1}$ Mpumalanga Department of Education, Siboniwe Primary School, Kwa-Mhlanga, South Africa. \\ ${ }^{2}$ Department of Information and Communication Technology, National Electronic Media Institute of South \\ Africa, Johannesburg, South Africa \\ *Correspondence: dsskosana@gmail.com
}

How to cite this paper: Ramaphakela, J., \& Mdhlalose, D. (2021). Examination of the Creation of a Positive Culture of Teaching and Learning through Classroom Management. Open Journal of Educational Research, 1(1), 32-40. Retrieved from https://www.scipublica-

tions.com/journal/index.php/ojer/article/view/127

Received: August 17, 2021

Accepted: September 22, 2021

Published: September 23, 2021

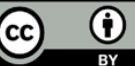

Copyright: () 2021 by the authors. Submitted for possible open access publication under the terms and conditions of the Creative Commons Attribution (CC BY) license (http://creativecommons.org/licenses /by/4.0/).

\begin{abstract}
This study aims to examine the creation of a positive culture of teaching and learning through classroom management to improve learner performance within the Kwa-Mhlanga NorthEast circuit in Mpumalanga province. This is a qualitative study that uses an inductive approach and a case study. For this study, interviews, observation, and document analysis were used to collect data. This study made use of thematic content analysis. Three schools were selected out of twentyfive and three participants from each school were representative of the entire population of one thousand one hundred educators in the circuit. Participants were selected purposively. The interviews were done face to face with participants from three sampled schools at scheduled times with each participant. This study found that the schools, namely School A, School B and School C use different policies in creating a positive culture of teaching and learning, policies such as staff attendance policy, assessment policy, learners code of conduct, classroom rules democratically developed, Both educators and learners lack the skill of time management and parents have deserted their responsibilities to guarantee that their children arrive on time at school, attend school daily, do the work given to them in class and discipline their children. The impact of harmonizing the creation of a positive culture of teaching and learning creates an environment where learners feel excited and positive to be part of the school and thus can take initiative. This study contends that there is a positive relationship between the positive culture of teaching and learning and classroom management. This study contributes to the body of knowledge for schools of education and training and development.
\end{abstract}

Keywords: Teaching and learning; learners; schools; education.

\section{Introduction}

The fight for freedom in South Africa led to a situation whereby education ended up being secondary to the attainment of freedom. That had an impact on how schooling was taken then. That was tantamount to ungovernability in every sphere of life education included. The impact of ungovernability in schooling was the corrosion and erosion of the culture of teaching and learning by the educational practitioners. This is precisely what is precipitating this research study. Regardless of major political changes and the nominal establishment of a single Ministry of National Education in July 1994, schools are still characterized by crime, bullying, inequality and a total lack of a culture of teaching and learning [1].

The South African education system was faced with several problems such as violence in schools, poor performance, inappropriate sanitation, and an increased rate of dropouts. This study examined the creation of a positive culture of teaching and learning to improve learner performance. The breakdown of the culture of teaching and learning 
in several South African schools, was reflected in multifaceted socio-educational problems encountered in schools, such as poor academic performance of learners, abuse of both educators and learners, high drop-out rate, and unmotivated learners as observable features of the poor culture of teaching and learning. [2] confirm that a significant problem that South African schools experienced was the restoration of a positive culture of teaching and learning. [3] echoed the same sentiment arguing that one of the main goals in education today was to restore the positive culture of teaching and learning to improve learner performance.

The problem of creating a positive culture of teaching and learning was in existence long before the dawn of democracy, efforts to improve have been tried, but still, it was evident that grade four learners are unable to read with meaning. The Department of Basic Education (DBE) also made efforts to establish a section called Culture of Learning, Teaching and Services (COLTS). [4] and [5] affirm that poor learner performance, poor management skills, poor attendance of both educators and learners, vandalism, drug abuse, high drop-out rate, and demotivation are some reasons schools have a poor culture of teaching and learning. The inability of schools to create a positive culture of teaching and learning to improve learner performance remains a problem in South Africa.

\section{Problem Statement}

A cause for concern in this study was that most poor learners are at risk of not achieving their educational dreams or goals [6]. Learners are unable to achieve their educational goals due to unstable classroom conditions and the unpleasant conditions of learning and teaching. [7] points out that no quality output can be achieved without relevant inputs. The current generation of learners within the South African education system does not display enthusiasm to learn, they do not have motivating factors from home to learn. Parents have neglected their duties to ensure that children arrive on time at school, attend school daily and do the work given to them in class. Thus, the problem identified in this study was the inability of schools to create a positive culture of teaching and learning through classroom management to improve learner performance remained a problem for most schools in this country, South Africa. Thus, South Africa was ranked number last out of fifty countries participating in Progress International Reading Literacy (PIRLS).

\section{Aim of the Study, Research Objectives and Research Questions}

\subsection{Aim of the study}

It is inconceivable to have a research study without an aim. In this context, this study aims to examine the creation of a positive culture of teaching and learning through classroom management to improve learner performance within the Kwa-Mhlanga North-East circuit in Mpumalanga province.

\subsection{Research Objectives}

The following objectives were persuaded to achieve the set aims:

- Research Objective 1: The study will examine how school communities in South Africa contribute to the creation of a positive culture of teaching and learning to enhance learner performance.

- Research Objective 2: To determine the role played by stakeholders within the school in creating a positive culture of teaching and learning.

- Research Objective 3: Highlight the gains of harmonizing the creation of a positive culture of teaching and learning and learner performance.

- Research Objective 4: Recommend ways and means of creating a positive culture of teaching and learning to improve South African learner's performance.

\subsection{Research Questions}


This study was generated by the following four research questions:

- Research Question 1: How can school communities in South Africa contribute to the creation of a positive culture of teaching and learning to enhance learner performance?

- $\quad$ Research Question 2: What role(s) can stakeholders in South African schools play in creating a positive culture of teaching and learning?

- Research Question 3: What are the gains of harmonizing the creation of a positive culture of teaching and learning on a South African learner's academic performance?

- Research Question 4: How can a positive culture of teaching and learning be created to improve South African learner's academic performance?

\section{Theoretical Framework}

[8] regards theories as being developed to justify the study under investigation aim to critically analyze the current findings and broaden the understanding of the phenomena. In this study, the researchers used constructivism as a process whereby; learners constructed their own understanding, reality, and knowledge of the world through interaction with educators in the creation of a positive culture of teaching and learning to improve learner performance.

This study aligned itself with the constructivist theory because learners are viewed as the leading role players in their learning process, with the ability to give a meaningful impact to the curriculum content they are taught. [9] continues to clarify constructivism as a limiting factor of education because educators cannot convey knowledge to learners, but learners critically and objectively construct knowledge in their minds. That is, learners explore and interpret information, verify new information against existing knowledge. Figure 1 represents the conceptual framework of this study.

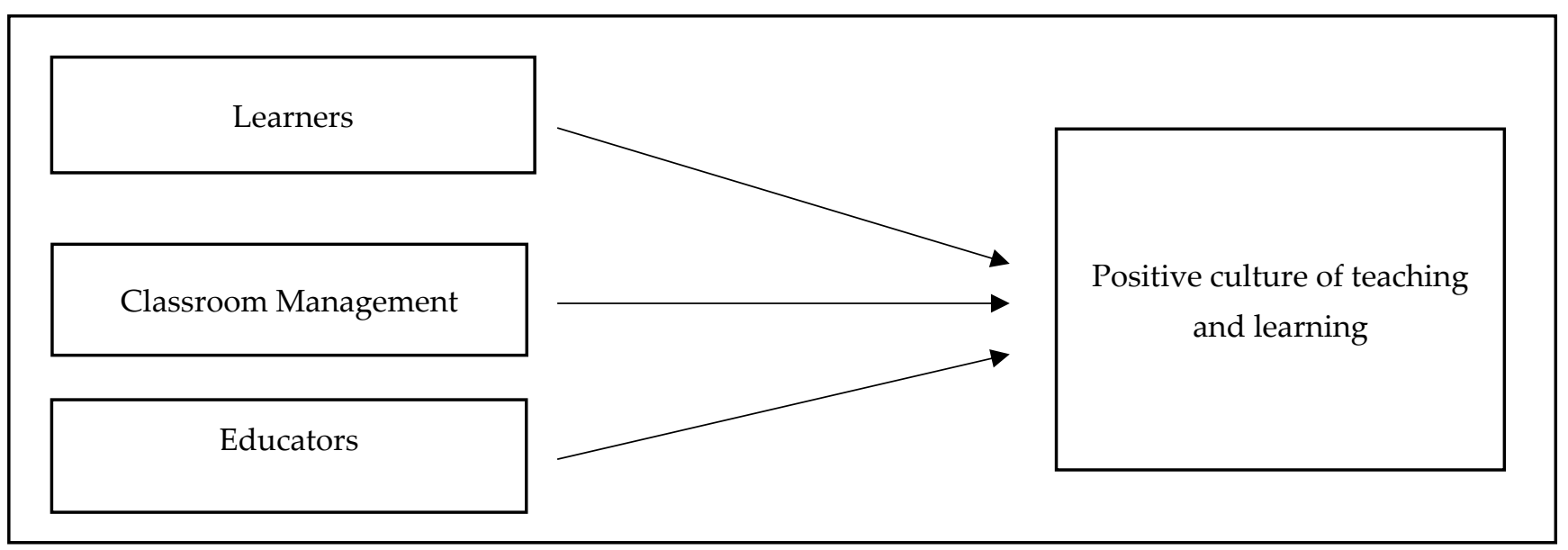

Figure 1. Conceptual Framework

\section{Literature Review}

Researchers and practitioners increasingly recognize that a positive school culture not only enhances the learner's day-to-day experiences but also plays a role in raising learners' achievement ([10-12]). School culture generally refers to the belief, perception, relationship; attitudes developed formally or informally to shape and influence every aspect of how a school function [13]. Poor performance of learners within the education system for several years, lack of learner discipline, low morale of both educators and learners, as well as other educational problems in some schools in South Africa prompted a call to improve the culture of teaching and learning across the country [14]. Effective teaching and learning are a major concern in many countries around the world. School culture involves common beliefs, customs and attitudes, rules and procedures developed over time and are shared by the school community. 
[15] and [16] describe a positive culture of teaching and learning as attitudes of educators and learners towards teaching and learning, and the spirit of dedication and commitment in a school which arises through the joint efforts of school management, the input of educators, personal characteristics of learners, factors in the family of learners, schoolrelated factors as well as societal factors. The nature of the physical environment and the availability of facilities and equipment are important elements in establishing a positive culture of teaching and learning in schools. Adequate and decent facilities and equipment create a positive environment in which effective teaching and learning can take place [17]. How both educators and learners respond to one another during the process of teaching and learning, the commitment they both display towards teaching and learning creates a conducive environment for teaching and learning.

The conflict generated in classes has a negative impact on learners and educators and is pedagogically unacceptable. The problem in South African schools is reflected through learners displaying poor reading skills, poor attendance by both educators and learners, over age learners, gang-related activities in schools [18]. Learners and educators who are committed to schoolwork end up feeling insecure and that feeling impedes their quest to meet their obligation of creating a positive culture of teaching and learning [19]. In a school with a positive culture of teaching and learning educator's morale is high, educators feel positive about each other and at the same time, experience a sense of accomplishment from their work [20]. A positive culture of teaching and learning engages learners constructively to achieve educational goals. [21] posit that a positive culture of teaching and learning is an environment where stakeholders value the processes of teaching and learning, and the day-to-day activities reflect the commitment to teaching and learning. A positive culture of teaching and learning reflects the convictions, values, and expectations of the members of the school that influences the attitudes and work practices of educators and learners as a determining factor in the culture of teaching and learning [22].

Teaching is an activity that educators do to transfer knowledge and skills to learners. [23] hold a view that teaching is a means to inculcate desirable changes in human abilities and behaviors. Educators had the task of arousing the interest of learners to participate actively in the process of teaching and learning. The researchers agreed that teaching involved not only behavior change, but also a means of sharing and communicating that usually resulted in the growth and development of learners in terms of knowledge, skills, and attitude. [24] throws further light on the concept of teaching by submitting that teaching is the process of guiding, stimulating, motivating, and evaluating the learner in an organized educational institution referred to as a school, through a planned and selected program of instructions towards the achievement of desired goals.

Several schools in South Africa, most importantly the ones that are disadvantaged or unable to create a positive culture of teaching and learning, therefore, struggle to achieve educational goals. [25] argues that the process of teaching in schools is in a bad state due to a lack of motivation and inadequate training for educators to face day-to-day challenges in class. Internationally, research has shown that teaching quality in education is imperative for the national development of any country, which advances the economic growth of the nation and at the same time increases the output of the affected educator [26]. [27], cites vandalism, gangsterism, drug abuse, a high drop-out rate, poor academic performance, and unmotivated learners as observable features of a poor learning culture. [28] claims that an important challenge facing South African schools is the restoration of a positive culture of teaching and learning. The researchers echo the same sentiment in arguing that one of the main goals in education today is to restore a culture of teaching and learning in South African schools [29]. The nurturing of a culture of learning within South African schools assumes a significant sense of importance if some of the social, educational, and socio-economic difficulties encountered in the country are to be addressed.

[30] refer to classroom management as actions that educators take to create a supportive environment for the academic and social emotions of learners. They describe five steps of actions to support effective classroom management as educators developing a 
caring, supportive relationship with and amongst learners, organizing and implementing instructions in ways that optimize learner's access to learning. Hence, classroom management is an ongoing interaction between educators and their learners towards the creation of a positive culture of teaching and learning. Educators play various roles in a typical classroom and one of the most important roles they play is to manage their classrooms to allow effective teaching and learning to take place. Creating a positive and open classroom climate is directly associated with the educator's classroom management practice. The style of classroom management or related matters within the classroom will determine the climate of the classroom which in turn will influence the attitude of the class [31]. The first aim of classroom management is to establish a quiet and calm environment in the classroom so that the learners can take part in meaningful learning in subjects [32]. The second aim is that classroom management contributes to the learner's social and moral development that has an impact on the development of learners academically and socially. [33] confirm that the classroom organization and a sound culture of teaching and learning competencies significantly influence the persistence of new educators in the teaching career.

Valuable teaching time is often lost through trying to maintain order. A positive sound culture of teaching and learning is essential in the South Africa educational institutions where all the role players share the same educational goals. An educator should develop a curriculum that provides them with clear goals for a learner's achievement. [34] suggests that the importance of curriculum planning is a tool for a well-ordered classroom, clarifying that educators who are proactive in planning and preparation, often find success with learners' behavior. Educators who are well prepared for their lessons rarely experience classroom management problems. The environment of a well-prepared educator creates a positive culture of teaching and learning. Educational goals are easily achieved in an environment where teaching and learning are learner centered. New educators typically express concerns about lacking effective means to handle the significant discipline behavior of learners [35]. Educators who have challenges with learners' conduct and classroom management are in most cases, ineffective in the classroom, and they often report levels of stress and symptoms of burnout [36]. Educators who are well prepared and have rich information related to the curriculum content of the grade and learners manage their classrooms effectively and are likely to create a positive culture of teaching and learning in their classes.

This study is likely to ensure educators view classroom management and teaching and learning as complementary to one another [37]. Educators who lack subject content and are not continually reskilling themselves experience problems in managing their classrooms making it difficult to create a positive culture of teaching and learning [38]. [39] contend that the environment within the classroom becomes stimulating for learners to learn effectively when they are learning without disturbances.

\section{Methodology}

A qualitative research approach was selected as the most appropriate approach to employ in collecting data to respond to the study research questions. The researchers used a case study approach to examine how schools can create a positive culture of teaching and learning through classroom management within the real-life context. [40] describe a case study as the study of instances in action. The design was chosen because of the philosophical assumption that knowledge comes from reality and that people produce reality. Thus, the study examined individual responses and explored the differences within and between cases to examine the creation of a positive culture of teaching and learning through classroom management [41]. This study made use of thematic content analysis to ensure that the views of educators were representative of their personal experience regarding the creation of the positive culture of teaching and learning to improve learner performance. The main aim of the researchers using thematic content analysis was to iden- 
tify patterns of meanings across data and give valuable responses to the research questions. Researchers investigated and analyzed the informants' input from their original state to interpret the creation of a positive culture of teaching and learning and the meaning stakeholders attached to it [42].

[43] posit that qualitative research provides an in-depth, intricate, and detailed understanding of meanings, actions, and observable as well as non-observable phenomena. That made the researchers believe that the strong points of the qualitative research approach would best suit the examination of the creation of a positive culture of teaching and learning and how it enhances the academic performance of learners. This study used purposive sampling because selected participants have some defining characteristics that made them holders of data relevant for the study [44]. Researchers identified participants based on the knowledge they pose concerning the phenomenon under investigation [45]. Interviews, observation, and document analysis were used to collect data. This study made use of thematic content analysis to ensure that the views of educators were representative of their personal experience regarding the creation of the positive culture of teaching and learning to improve learner performance. For this study, a population was referred to as a collection of educators around the Kwa-Mhlanga circuit. Three schools were selected out of twenty-five and three participants (namely: 3 deputy-principals, 3 Head of Departments (HOD) and 3 educators) from each school representative of the entire population of one thousand one hundred educators in the circuit. Participants were purposively selected on the basis that they supplied relevant and rich data regarding the phenomenon [46].

\section{Data Analysis and Reporting}

Semi-structured interviews, observations and document analysis were conducted at individual schools following appointments with respective principals. The interviews were conducted face to face with participants from three sampled schools at scheduled times with each participant. The biographical information of participants includes the position participant holds at the school, gender, post level and the teaching experience see Table 1. This information was important because it provided an overview of the information participants provided in the study. A highly experienced participant is more likely to provide rich information relevant to the study.

Table 1. Biographical information of the participants involved in the study

\begin{tabular}{cccc}
\hline Participant position and code & Gender & Post level & Experience in teaching \\
\hline Deputy Principal (A) & Female & 3 & 23 years \\
\hline Deputy-Principal (D) & Male & 3 & 34 years \\
\hline Deputy Principal (G) & Male & 3 & 16 years \\
\hline HOD (B) & Male & 2 & 9 years \\
\hline HOD (E) & Female & 2 & 27 years \\
\hline HOD (H) & Male & 2 & 7 years \\
\hline Educator (C) & Female & 1 & 20 years \\
\hline Educator $(\mathrm{F})$ & Female & 1 & 31 years \\
\hline Educator $(\mathrm{I})$ & Female & 1 & 30 years \\
\hline
\end{tabular}

\subsection{Results and Discussion}

This study found that the schools namely School A, School B and School C use different policies in creating a positive culture of teaching and learning, policies such as staff attendance policy, assessment policy, code of conduct, classroom rules democratically developed, continuous assessment and feedback given to learners, motivation given to both educators and learners and recognition of good work in form of awards contribute positively to the creation of a positive culture of teaching and learning. This study found that 
both educators and learners lack the skill of time management. Parents have deserted their responsibilities to guarantee that their children arrive on time at school, attend school daily, do the work given to them in class and discipline their children. This study found that educators create a positive culture of teaching and learning through classroom management by enforcing discipline through order in the classroom because order advances a sound culture of teaching and learning and responsibility. Learners must know their responsibility, and educators also should know their responsibility is to teach learners and learners' responsibility is to learn.

This study found that effective time management is a skill that is required by all educators and learners. Educators were using various strategies to collaborate with learners such as establishing clear goals, establishing flexible group norms, keeping groups midsized, building trust, and promoting effective and open communication. However, this study also found that educators are struggling to manage their classrooms which ultimately impact the creation of a positive culture of teaching and learning within the classes. The three schools' policies were adopted and signed by subject educators within a specific department. Staff profiles revealed that most educators were not allocated subjects according to their skills and qualifications. This study found that the impact of harmonizing the creation of a positive culture of teaching and learning creates an environment where learners feel excited and positive to be part of the school and thus can take initiative. Learners feel valued, supported, stimulated, attracted, and positively challenged. As a result, learners' academic performance improves and becomes better because of the positive surrounding environment.

\subsection{Limitations of the study}

The first limitation of this study was its sampling. The study sampled only three primary schools where a deputy-principal, HOD and an educator post level one, were participants. The narrowness of this sampling becomes a limitation of the study because what is found in those schools could not be generalized or applicable to other schools. Another limitation of this study is the findings that emerged with the fact that only one deputy, one HOD and one educator represented the sampled schools, compromising the vastness of the concluded findings.

\subsection{Suggestions for future researchers}

The following future or further research studies are being proposed:

- $\quad$ Further studies could apply a quantitative method or mixed study.

- This research study was conducted at the Kwa-Mhlanga circuit in Mpumalanga province. The same study can be carried out in another circuit.

- A comparative study of both public and private sector schools in the same region can be carried out.

\section{Recommendations Conclusion}

A review of the literature and the primary research findings provide the basic foundations for the following recommendations:

- $\quad$ Educators need to work based on time and attendance as well as teaching schedules and discipline must be applied within that space.

- $\quad$ Educators should create and control regulations or rules to manage discipline in class that would support achieving the educational goals.

- Classroom norms should be posted on walls so that all learners can be aware of them and be accountable accordingly.

- Parents should make sure that children arrive on time at school, attend school daily, do the work given to them in class and are disciplined.

- Learners should know that their responsibility is to learn and be always disciplined. 


\section{Conclusion and Implications}

This research study focused on an examination of the creation of a positive culture of teaching and learning through classroom management. Based on the research findings of this study, the study concludes by stating that factors influencing learners' performance and educational outcomes in the three schools are amongst others disobedience, rudeness and verbal aggression displayed by learners of various ages, lack of interest, lack of motivation, learners seeking attention, classroom conditions unwelcoming, educators' attitude towards learners and family background, lack of planning by educators, performance pressure from the school administrators, overcrowding of classes, learners with behavioral problems vandalism, gangsterism, drug abuse, and limitation of resources to enhance their teaching and learning in classes. The above-mentioned factors make it difficult to create a positive culture of teaching and learning through classroom management, especially in the disadvantaged schools in South Africa. This study confirms that there is a positive relationship between a positive culture of teaching and learning and classroom management. This study contributes to the body of knowledge for schools of education and training and development. Furthermore, this research finding adds value to the research knowledge of the Mpumalanga department of education and Kwa-Mhlanga circuit

School communities contribute and create a positive culture of teaching and learning through collaboration and collective awareness. Educators should maintain the learning setting and environment safe for learners to promote their morale and willingness to learn. All learner's dignity should be respected and protected regardless of their learning abilities and styles. Educators should foster positive discipline rather than consequential responses to managing ill-discipline. Children function well if there are clearly outlined routines for them in class as a way of managing the classroom. Educators should be encouraged to develop routines such as mental mathematics in the morning or phonics. Educators should be encouraged to arrange their physical environment of classes, classes should be cleaned, desks should be well arranged, and learners arranged according to their learning abilities. Learners' attributes, social interactions with peers and educators contribute a lot to the performance of learners.

\section{Competing Interests}

Authors have declared that no competing interests exist.

\section{References}

[1] Christie, P. (1991). The right to learn. The struggle for education in South Africa (expanded edition). Johannesburg: Ravan Press.

[2] Van Deventer, I. \& Kruger, A.G. (2003). (Eds). An Educator's Guide to school management. Pretoria: Van Schaik.

[3] Hesytek, J. \& Lethoko, M.X. (2001). The contribution of teacher unions in the restoration of teacher professionalism and the culture of learning and teaching. South African Journal of Education.

[4] Mona, D. (1997). Stress management in schools. Beverly Hills: Sage.

[5] Van Schalkwyk, O.J. (1994). The education system. Theory and practice. Pretoria: Alkanto.

[6] Chan, M.A. \& Hansen, K. (2017). “The early years: silent emergency of unique opportunity? “The Lancet, 389 (10064): 11-13.

[7] West-Burnham, J. (1992). Managing quality in schools. Essex: Longman.

[8] Abend, G. (2008). The meaning of theory. A theory building in applied disciplines. San Francisco: Berret-Koehler Publishers.

[9] Vygotsky, L. (1962). Thought and language. (E. Harfmann \& G. Vakar, Trans.). Cambridge: MIT Press.

[10] Kraft, M.A., Marine, W.H. \& Shen-Wei Yee, D. (2016). School Organizational Contexts, Teacher Turnover and Student Achievement: Evidence from Panel Data. American Educational Research Journal.

[11] Fergus, E., Noguera, P. \& Martin, M. (2014). Schooling for resilience: Improving the life trajectory of Black and Latino boys. Cambridge, MA: Harvard Education Press.

[12] Bryk, S. (2010). Organizing Schools for Improvement. online: https://journals.sagepub.com/

[13] Barnes, K., Brynard, S. \& De Wet, C. (2012). The influence of school culture and school climate on violence in schools of the Eastern Cape Province. South African Journal of Education, 32: 69-82.

[14] Lethoko, M.X. (1999). Restoring the culture of learning and teaching in secondary schools in the Pretoria area. MEd dissertation. Pretoria: University of Pretoria.

[15] Smith, H.J. (1996). Ability and outcome evaluations as a function of personal and collective disadvantage. A group escape from individual bias Personality and Psychology Bulletin: Nelson-Hall. 
[16] Pacheco, R. (1996). Learning culture in schools of the former Department of Education and Training. The dissertation. Johannesburg: Rand African University.

[17] Chisholm, L. \& Vally, S. (1996). The culture of learning and teaching in Gauteng schools. Education Policy Unit. Johannesburg: University of the Witwatersrand.

[18] Christie, P. (1991). The right to learn. The struggle for education in South Africa (expanded edition). Johannesburg: Ravan Press.

[19] Zulu, B.M. (1999). The teacher's responsibility pertaining to a culture of learning. Med dissertation. Umlazi: University of Zululand.

[20] Hoy, W.K. \& Miskel, G.G. (1987). Educational administration: Theory, Research and Practice. New York: Random House Trade.

[21] Davidoff, S. \& Lazarus, S. (1997). The learning school: an organization development approach. Cape Town: Juta.

[22] Hoy, W.K. \& Forsyth, P.B. (1986). Effective supervision: Theory into practice. New York: Random House.

[23] Olaitan, S.O. \& Agusiobo, N.O. (2001). Principles of practice teaching. New York.

[24] Ordor, A.J. (2001). A re-determination of the trichromatic coefficients of the spectral colours. New York: Oxford University.

[25] Wedgwood, R. (2007). Education and poverty reduction in Tanzania. International Journal of Educational Development.

[26] Hanushek, E.A. \& Woessman, L. (2007). The role of school improvement in economic development. National Bureau of Economic Research Working Paper.

[27] Masitsa, M.G. (2005). The principal's role in the restoring a learning culture in township secondary schools. Africa education review, 2:205-220.

[28] Van Deventer, I. \& Kruger, A.G. (2003). (eds). An Educator's Guide to School management. Pretoria: Van Schaik.

[29] Lethoko, M.X. (1999). Restoring the culture of learning and teaching in secondary schools in the Pretoria area. MEd dissertation. Pretoria: University of Pretoria.

[30] Evertson, L.M. \& Weinstein, C.S. (2006). Classroom management as a field of Inquiry, in C.M. Evertson\& C. S Weinstein (Eds) Handbook of classroom management: research, practice, and competence issues, pp. 97-125. Mahwah, N.J: Lawrence Erlbaum.

[31] Kruger, A.G. \& Van Schalkwyk, O.J. (1997). Classroom Management; $2^{\text {nd }}$ Revised edition. Van Schaik: Pretoria.

[32] Doyle, W. (1986). Classroom organization and management, in M. Wittrock (Ed) Handbook on Research on Teaching (3 $3^{\text {rd }}$ ed.) pp. 392-431 London: Macmillan.

[33] Ingersoll, R.M. \& Smith, T.M. (2003). The wrong solution to the teacher shortage. Educational Leadership, 60(8): 30-33.

[34] Bauer, P. (2001). Over-ocean rainfall retrieval from multisensory data of the Tropical Rainfall Measuring Mission (TRMM). Part I: Design and evaluation of inversion databases. J. Atmos. Oceanic Technol. 18, 315-330.

[35] Brovers., A. \& Tomic, W. (2000). A longitudinal study of teacher burnout and perceived self-efficiency in classroom management. Teaching and teacher education, 16(2): 239-253.

[36] Berliner, D.C. (1986). In pursuit of the expert pedagogue. Educational Researcher, 15(7): 5-13.

[37] Belknap, B. \& Taymans, J. (2015). Risk and resilience in beginning special education teachers; Apprenticeship, 4, 1-19.

[38] Ravhuhali, F., Kutame, A. P. \& Mutshaeni, H.N. (2015). Teachers' perceptions of the impact of continuing professional development on promoting quality teaching and learning, International Journal of Education Science, 10(1): 1-7.

[39] Cooper, J.T. \& Scott, T.M. (2017). The Keys to Managing Instruction and Behaviour: Considering High Probability Practices. Journal of Teacher Education and Special Education. 40(2): 102-113 https://doi.org/10.1177/0888406417700825.

[40] Cohen, L., Manion, L. \& Morrison. K.R.B. (2000). Research Methods in Education (5 $5^{\text {th }}$ ed). London: Routledge Falmer.

[41] Myers, M.D. (2009). Qualitative research in business \& management. London: Sage Publications.

[42] Attalah, D.G. (2017). "A community-based qualitative study of intergenerational resilience with Palestine refugee families facing structural violence and historical trauma" Transcultural Psychiatry, 54 (3): 357-383.

[43] Cohen, L., Manion, L. \& Morrison, K.R.B. (2011). Research Methods in Education (7 ${ }^{\text {th }}$ ed). London: Routledge Falmerh.

[44] Maree, K. (2007). First Steps in Research. Pretoria: Van Schaik Publishers.

[45] McMillan, J.H. \& Schumacher, S. (1993). Research in Education. A conceptual introduction (3rd ed.). New York: HarperCollins College Publishers.

[46] Maree, K. (2007). First Steps in Research. Pretoria: Van Schaik Publishers. 